\title{
LAJU DEKOMPOSISI SPESIES TANAMAN PENGAKUMULASI KALSIUM (CA) TINGGI DAN RENDAH DI DAERAH HUTAN HUJAN TROPIS SUPER BASAH PADANG SUMATRA BARAT
}

\author{
Hermansah, Burhanudin and Sri Muhara \\ Jurusan Tanah Fakultas Pertanian Universitas Andalas.
}

\begin{abstract}
Study on decomposition rate of accumulating and excluder tree species of calsium (Ca) was conducted in a super wet tropical rain forest in Gadut Mountain Padang West Sumatra. The purposes of the study were : (1) to understand the rate of decomposition of biomass of Ca accumulating and excluder tree species, (2) to understand the effect of slope position (ridge, midle and lower slope) on decomposition rate within the study plot and (3) to understand the amount of nutrient release to soil ecosystem within certain period. The result of this study showed that the higher decompoisition rate among two species was Eugenia $s p$, as Ca accumlating tree species which grew at lower slope. Six months after decomposition, 1 ton dry biomass of Eugenia sp contributed 6,8 kg N, 0,4 kg P, 4,12 kg K, 38,76 kg Ca, and 2,1 kg Mg in to the soil. This amount might keep an equilibrium of soil nutreint balance to support the forest ecosystem. However, for one ton dry mass of Lithocarpus korthalsii sp as Ca exluder tree species, after 6 months decomposition, contributed 9,4 kg N, 1,1 kg P, 4,61 kg K, 3,76 kg Ca and $0,54 \mathrm{~kg} \mathrm{Mg}$. This indicates that $\mathrm{Ca}$ acumulating tree species contributed more Ca compared to Ca excluder tree species in this forest ecosystem.
\end{abstract}

Keywords: Accumulating tree sp., exluder tree sp., decomposition rate, super wet and tropical rain forest.

\section{PENDAHULUAN}

Hutan Pinang-Pinang yang menjadi lokasi plot penelitian ekologi tumbuhan dan tanah adalah merupakan hutan hujan tropis super basah yang kaya dengan jenis spesies tumbuhan (Hermansah et al, 2003). Tingginya keragaman spesies tumbuhan yang ditemukan pada 1 ha plot peneltian ini juga memperlihatkan keragaman karakteristik kandungan unsur hara yang tinggi baik pada daun maupun pada kulit dan batang tumbuhan (Masunaga et al.,1977).

Siklus hara melalui runtuhan serasah daun yang jatuh mempunyai hubungan yang posisitf dengan kadar unsur hara dalam tanah. Kajian tingkat dekomposisi serasah daun tumbuhan yang kembali ke tanah melalui runtuhan serasah (litterfall) sangat penting dilakukan dalam rangka melihat dinamika siklus hara pada ekosistm hutan. Litterfall merupakan mekanisme utama siklus hara pada ekosistem hutan (Regina dan Tarazona, 2001). Banyak peneltian yang dilakukan untuk mempelajari tentang dinamika runtuhan sarasah dan siklus haranya di hutan hujan tropik di berbagai wilayah (Jordan, 1985; Vitousek, 1982, 1984). Akan tetapi, penelitian mengenai dekomposisi serasah untuk jenis spesies tertentu yang dicirikan oleh kadar unsur hara yang dikandungnya belum banyak dilakukan. Hermansah et al, (2002) menyatakan bahwa diantara delapan unusr hara yang dinalisis (N, P, K, Ca, Mg, Al, Fe dan S) kasium (Ca) memperlihatkan konsentrasi dan jumlah hara yang paling banyak terkandung dalam serasah daun tumbuhan.

Dilain pihak Masunga et al, ( 1997) menyatakan bahwa sebagain besar tumbuhan di Pinang-pinang mengakumulasi unsur hara yang sangat bervariasi. Tumbuhtumbuhan yang mempunyai diameter batang (DBH) diatas $8 \mathrm{~cm}$ dari hasil analisis kandungan haranya dapat dikelompokkan kepada tumbuhan-tumbuhan yang mengandung hara tinggi (accumulator tree sp.) dan tumbuhan yang mengandung hara rendah (excluder tree $s p$.). Bervariasinya kandungan hara dari beberapa spesies tumbuhan pada hutan ini jelas akan memberikan kontribusi yang berbeda dalam menyumbangkan hara melalui proses dekomposisinya. 
Bertitik tolak dari latar belakang pemikiran tersebut maka dilakukan penelitian tentang kajian kecepatan dekomposisi dari biomasa daun tumbuhan yang mengandungan $\mathrm{Ca}$ tinggi dan yang rendah. Penelitian dilakukan dengan tujuan untuk mengetahui kecepatan dekomposisi daun tumbuhan yang berkadar Ca tinggi dan yang berkadar $\mathrm{Ca}$ rendah dan untuk mengetahui besarnya sumbangan unsur hara dari tumbuhan spesifik mengandung hara tersebut ke tanah dalam waktu tertentu.

\section{BAHAN DAN METODA}

\section{Waktu dan Tempat}

Penelitian ini dilaksanakan pada plot penelitian ekologi hutan dan tanah di Pinang Pinang yang terletak di kaki Gunung Gadut, $18 \mathrm{~km}$ dari bagian timur Kota Padang dari bulan Februari sampai Agustus 2004. Analisis unsur hara daun tumbuhan dan hasil dekomposisi dilakukan di laboratorium Pusat Penelitian Pemanfaatan Iptek Nuklir (P3IN) Universitas Andalas Padang.

Bahan yang digunakan dalam penelitian ini adalah daun segar tua Lithocarpus korthalsii sp. (berkadar Ca rendah) dan Eugenia sp (berkadar Ca tinggi). Sedangkan alat-alat yang digunakan adalah litter bag yang terbuat dari nilon dengan ukuran lubang $1 \mathrm{~mm}$ berukuran $20 \mathrm{x}$ $10 \mathrm{~cm}$, kantong plastik. Untuk melindungi sampel dari ganguan binatang digunakan jaring dari kawat halus.

\section{Metoda Penelitian}

Dalam penelitian ini digunakan rancangan faktorial 2 x 3 dalam Rancangan Acak Kelompok. Faktornya terdiri dari 2 spesies tumbuhan (spesies tumbuhan yang berkadar Ca tinggi dan yang berkadar Ca rendah) dan ditempatkan pada 3 posisi topografi (puncak bukit, tengah lereng, dan kaki bukit) dengan 3 kelompok. Untuk melihat perbedaan kecepatan dekomposisi dari dua jenis spesies ini pada setiap posisi topografi dan waktu tertentu dianalisis dengan uji $\mathrm{F}$ (Fisher test) pada taraf $5 \%$ dan $1 \%$ dan uji lanjut BNT pada taraf $5 \%$.

\section{Pengumpulan Sampel}

Sampel daun diambil dengan cara memanjat pohon (dengan bantuan buruh) dari sampel tumbuhan yang berkadar Ca tinggi (Eugenia $s p$ ) dan berkadar Ca rendah (Lithocarpus korthalsii). Sampel daun yang diambil adalah daun yang sudah tua, secara visual terlihat sudah keras, warnanya hijau tua atau mendekati kuning. Banyak sampel yang diambil kira-kira 2 kg masing-masing spesies, untuk mendapatkan berat kering 540 g. Selanjutnya daun-daun tersebut dikeringkan dalam oven selama 2 x 24 jam pada suhu $60^{\circ} \mathrm{C}$ sampai beratnya konstan (Yoneda et al, 1977 cit Hotta et al, 1984). Ini digunakan untuk bahan dekomposisi.

\section{Dekomposisi}

Daun-daun yang sudah dioven dimasukkan kedalam litter bag berukuran 20 cm x $10 \mathrm{~cm}$ sebanyak $10 \mathrm{~g}$ berat kering per litter bag (Users, 1999). Kemudian didekomposisikan dengan meletakkannya di permukaan tanah pada tiga posisi topografi yang berbeda untuk masa dekomposisi 1, 2, 3, 4, 5 dan 6 bulan dengan 3 ulangan (total adalah 108 sampel). Untuk menghindari agar sampel tidak diganggu binatang besar dan hanyut serta gangguan lain, litter bag tersebut ditutup dengan kotak kawat.

\section{Pengambilan Sampel dan Analisis di Laboratorium}

Pengambilan sampel dalam litter bag yang sudah didekomposisi dilakukan setiap bulannya. Sampel diambil dengan hati-hati setiap bulan (9 litter bag per spesies), jadi jumlah sampel setiap bulannya 18 untuk 2 spesies dan dibawa ke laboratorium. Litter bag dibersihkan dengan hati-hati untuk membersihkan tanah dan bahan-bahan lain yang menempel di litter bag (Anderson and Ingram, 1989 cit Jamaludheen, 1998). Sisa biomassa tersebut dipindahkan dari litter bag, kemudian dikeringkan di oven pada suhu $60^{\circ} \mathrm{C}$ selama 48 jam dan ditimbang berat kering yang tersisa. Sampel yang sudah kering digrinder menjadi tepung dengan menggunakan grinder, kemudian disimpan dalam plastik tertutup yang kedap udara dan digunakan untuk analisis.

Analisis dilaboratorium dilakukan untuk mengetahui kandungan hara pada sampel sebelum dan sesudah didekomposisi. 
Analisis awal / sebelum dekomposisi meliputi kadar air, kadar lignin, luas daun dan kandungan hara sebelum dekomposisi. Setiap bulannya, diukur kehilangan berat biomass dan unsur hara meliputi N, P, K, Ca, Mg dan C-total. Dimana unsur N, P, K, Ca dan Mg diukur dengan metoda dekstruksi basah. Sedangkan C-total karena keterbatasan alat, yang diukur hanya Corganik diukur dengan metoda pengabuan. Untuk melihat pola dari kehilangan berat biomass daun kadar unsur hara dalam bahan yang didekomposisi ditampilkan dalam bentuk Gambar dan Tabel.

\section{Analisis Data}

Data yang diperoleh dari analisis laboratorium akan diolah untuk mengetahui korelasi antara tingkat dekomposisi dan berat biomass yang hilang akibat dekomposisi. Model konstan berat potensial yang hilang atau koefisien tingkat dekomposisi dapat dianalisis dengan persamaan Olson (Olson, 1963 cit Sundarapandian, 1999).

Persamaannya adalah sebagai berikut :

$$
\frac{X}{X o}=e^{-k t}
$$

$$
\text { Dimana : } \quad \begin{gathered}
\mathrm{X}=\text { berat sisa serasah pada } \\
\text { waktu } \mathrm{t} \\
\mathrm{Xo}=\text { berat awal serasah } \\
\mathrm{k} \quad=\text { koefisien kecapatan } \\
\quad \text { dekomposisi } \\
\mathrm{t} \quad=\text { waktu (tahun) }
\end{gathered}
$$

$$
\mathrm{e}=\text { bentuk dasar logaritma }
$$

Dari persamaan diatas dapat dikonversikan kedalam bentuk $\mathrm{ln}$, untuk mendapatkan tetapan $\mathrm{k}$ (koefisien kecepatan dekomposisi).

$$
\begin{aligned}
& \frac{X}{X o}=e^{-k t} \quad e^{-k t}=\frac{X}{X o} \\
& -k t=\ln (\mathrm{X} / \mathrm{Xo}) \\
& \mathbf{k}=-\frac{\ln \left(x_{/} /{ }\right)}{t}
\end{aligned}
$$

\section{HASIL DAN PEMBAHASAN}

\section{Keadaan Umum Plot Penelitian}

Plot penelitian Pinang Pinang didirikan pada tahun 1981 oleh Hotta dan Ogino di sepanjang lereng Gunung Gadut. Plot penelitian ini didirikan untuk melakukan berbagai macam bidang

\begin{tabular}{|c|c|c|c|}
\hline No & Sifat Kimia Tanah & Total & Kriteria** \\
\hline 1 & pH H2O & 4,4 & Masam \\
\hline 2 & $\mathrm{pH} \mathrm{KCl}$ & 4,3 & Masam \\
\hline 3 & N (\%) & 47 & Sedang \\
\hline 4 & $\mathrm{P}(\mathrm{ppm})$ & 5,56 & Rendah \\
\hline 5 & K (me/100 g) & 0,27 & Rendah \\
\hline 6 & Ca (me/100 g) & 9,60 & Tinggi \\
\hline 7 & Mg (me/100 g) & 0,68 & Rendah \\
\hline 8 & $\mathrm{C} / \mathrm{N}$ & 13,2 & Sedang \\
\hline
\end{tabular}
penelitian di bidang ekologi hutan dan tanah. Plot penelitian ini mempunyai curah hujan tahunan yang tinggi yaitu lebih dari 5000 $\mathrm{mm}$ pertahun tanpa musim kering (Hotta et $a l$, 1984). Ordo tanah pada plot penelitian ini adalah Inceptisols yang berkembang dari batu karang dan andesit (Wakatsuki, Saidi, Rasyidin, 1986). Sifat kimia tanah plot penelitian ini disajikan pada Tabel 1.

Tabel 1. Sifat kimia tanah pada plot penelitian Pinang Pinang* 
Pada Tabel 1 terlihat bahwa tanah pada plot penelitian memiliki kesuburan tanah yang rendah. Nilai $\mathrm{pH}$ tanah yang rendah dan kandungan unsur hara yang rendah disebabkan oleh tingginya curah hujan sehingga mengakibatkan tercucinya unsur hara.

\section{Karakteristik Daun Spesies Tumbuhan Yang Didekomposisi.}

Daun yang didekomposisi yaitu daun tumbuhan yang berkadar Ca tinggi (Eugenia $s p$ ) dan daun tumbuhan yang berkadar Ca rendah (Lithocarpus korthalsii). Tumbuhan Eugenia sp dikatakan berkadar Ca tinggi karena merupakan 5\% dari tumbuhan yang memiliki kandungan $\mathrm{Ca}$ yang tertinggi dari 700 tumbuhan yang dianalisis. Sedangkan Lithocarpus korthalsii dikatakan berkadar $\mathrm{Ca}$ rendah karena merupakan 5 \% dari tumbuhan memiliki kandungan $\mathrm{Ca}$ yang terendah dari 700 tumbuhan yang dianalisis (Masunaga et al, 1997). Karakteristik unsur hara pada daun yang didekomposisi disajikan pada Tabel 2.

Tabel 2. Karakteristik daun yang didekomposisi ${ }^{*}$ )

\begin{tabular}{lcc}
\hline $\begin{array}{c}\text { Karakteristik } \\
\text { Daun }\end{array}$ & Eugenia sp & L. korthalsii \\
\hline Lignin (\%) & 25,25 & 28,74 \\
Luas $\left(\mathrm{cm}^{2}\right)$ & 29,5 & 91,6 \\
$\mathrm{~N}(\mathrm{~g} / \mathrm{kg})$ & 9,72 & 17,96 \\
$\mathrm{P}(\mathrm{g} / \mathrm{kg})$ & 0,54 & 1,35 \\
$\mathrm{~K}(\mathrm{~g} / \mathrm{kg})$ & 4,59 & 8,95 \\
$\mathrm{Ca}(\mathrm{g} / \mathrm{kg})$ & 43,16 & 9,32 \\
$\mathrm{Mg}(\mathrm{g} / \mathrm{kg})$ & 2,33 & 1,06 \\
$\mathrm{C} / \mathrm{N}$ & 44,26 & 27,08
\end{tabular}

${ }^{*}$ Masunaga et al, 1997

Dari Tabel 2 dapat terlihat bahwa kadar lignin Eugenia sp lebih rendah daripada kadar lignin Lithocarpus korthalsii, dimana kadar lignin Eugenia sp 25,25 \% atau 3,49 \% lebih rendah daripada Lithocarpus korthalsii yang mempunyai kadar lignin 28,74 \%. Begitu juga dengan luas daun, dimana luas daun Lithocarpus korthalsii jauh lebih luas dari Eugenis $s p$ yaitu sebesar $91,6 \mathrm{~cm}^{2}$ atau $62,1 \mathrm{~cm}^{2}$ lebih luas dari Eugenia sp yang hanya memiliki luas daun $29,5 \mathrm{~cm}^{2}$.

Kandungan N, P, dan $\mathrm{K}$ tertinggi juga terdapat pada Lithocarpus korthalsii dimana kandungan N-nya 8,24 g/kg, P 0,81 $\mathrm{g} / \mathrm{kg}$, dan $\mathrm{K} 4,36 \mathrm{~g} / \mathrm{kg}$ lebih tinggi dari Eugenia sp. Sedangkan kandungan Ca, Mg, dan $\mathrm{C} / \mathrm{N}$ terlihat lebih tinggi pada Eugenia $s p$ dari pada Lithocarpus korthalsii yaitu kandungan Ca pada Eugenia sp 33,84 mg/kg lebih tinggi dari pada Lithocarpus korthalsii (hampir 5 kali). Sementara kandungan $\mathrm{Mg}$ Eugenia sp 17,18 $\mathrm{mg} / \mathrm{kg}$ lebih tinggi daripada Lithocarpus korthalsii.

\section{Perubahan Berat Kering Bahan Selama 6 Bulan Dekomposisi}

Pada proses dekomposisi, berat serasah yang tersisa menurun dari waktu ke waktu (Hobbie dan Vitousek, 2000). Berat kering serasah yang tertinggal selama 6 bulan hampir $25 \%$ untuk tumbuhan berkadar $\mathrm{Ca}$ tinggi dan $40 \%$ untuk tumbuhan berkadar Ca rendah. Perubahan bobot kering selama proses dekomposisi pada 3 posisi topografi dapat dilihat pada Gambar 1.

Penurunan berat kering merupakan suatu tanda terjadinya proses dekomposisi. Dari Gambar 1 dapat dilihat bahwa persentase berat kering yang tersisa untuk kedua spesies tumbuhan yaitu Eugenia $s p$ (tumbuhan berkadar Ca tinggi) dan Lithocarpus korthalsii (tumbuhan berkadar Ca rendah) menurun setiap bulannya selama proses dekomposisi. Proses dekomposisi untuk spesies tumbuhan Eugenia $s p$ menurun secara cepat sampai dengan bulan ke-3, selanjutnya sampai bulan ke-6 penurunan yang terjadi tidak begitu nyata. Sedangkan pada spesies tumbuhan Lithocarpus korthalsii penurunan berat kering sampai dengan bulan ke-6. 

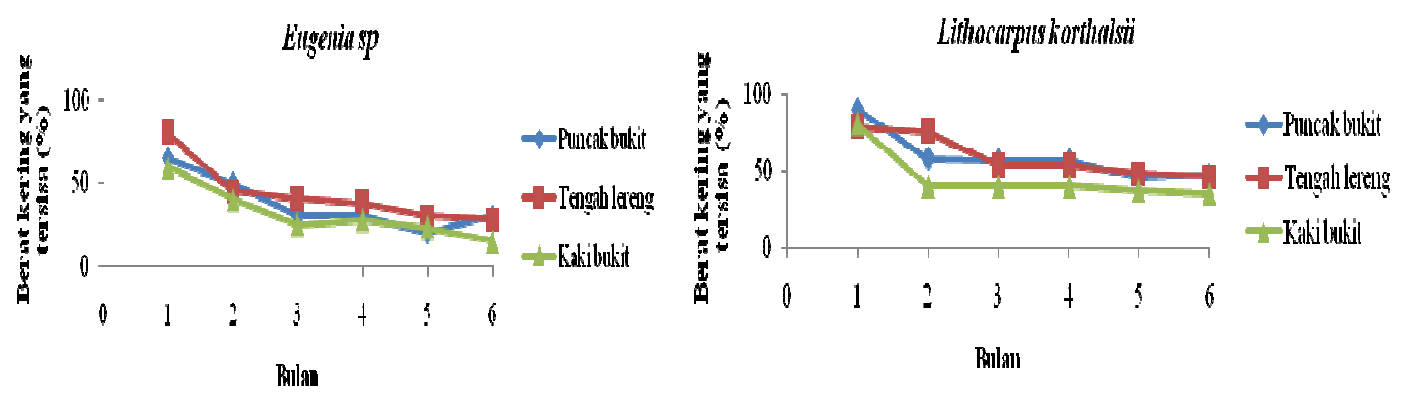

Gambar 1. Fluktuasi perubahan berat kering 2 jenis spesies tumbuhan pada posisi topografi selama 6 bulan proses dekomposisi

Penurunan berat kering yang lebih cepat didapatkan pada spesies tumbuhan Eugenia $s p$ bila dibandingkan dengan Lithocarpus korthalsii. Perbedaan penurunan berat kering ke-2 jenis spesies tumbuhan ini disebabkan oleh perbedaan kandungan unsur haranya dan kandungan lignin. Eugenia sp memiliki lignin yang lebih rendah dari Lithocarpus korthalsii sp. Lignin merupakan senyawa yang paling resisten sehingga sukar didekomposisi (Hakim et al, 1986) dan lebih lanjut Hobbie dan Vitousek (2000) menyatakan bahwa lignin dapat menghambat proses dekomposisi.

\section{Kecepatan Dekomposisi}

Koefesien kecepatan dekomposisi (k) merupakan suatu peubah untuk menentukan kecepatan dekomposisi. Nilai k yang tinggi menunjukkan kecepatan dekomposisi yang tinggi juga. Untuk membandingkan nilai k pertahun ke-2 jenis spesies tumbuhan disetiap posisi topografi digunakan persamaan Olsen. Tabel 5 memperlihatkan nilai $\mathrm{k}$ masing-masing spesies (Eugenia sp dan Lithocarpus korthalsii) pertahun.

Tabel 3 menunjukkan bahwa Eugenia sp memiliki koefisien kecepatan dekomposisi (k) yang lebih tinggi dari pada Lithocarpus korthalsii disetiap posisi topografi. Tingginya nilai $\mathrm{k}$ ini menandakan bahwa Eugenia sp lebih cepat terdekomposisi dibandingkan Lithocarpus korthalsii. Pada puncak Eugenia sp memiliki nilai k 2,6 sedangkan Lithocarpus korthalsii 1,57. Hal serupa juga terjadi pada posisi topografi lereng maupun kaki. Pada lereng nilai $\mathrm{k}$ Eugenia sp 2,73 sedangkan Lithocarpus korthalsii 1,68. Begitu juga dengan posisi kaki dimana nilai k Eugenia sp 3,46 sedangkan Lithocarpus korthalsii hanya 2,35.

Tabel 3. Koefesien kecepatan dekomposisi (k)

\begin{tabular}{lcc}
\hline Posisi & $\begin{array}{c}\text { Eugenia } \\
s p\end{array}$ & $\begin{array}{c}\text { Lithocarpus } \\
\text { korthalsii }\end{array}$ \\
\hline Puncak bukit & 2,60 & 1,57 \\
Tengah lereng & 2,73 & 1,68 \\
Kaki bukit & 3,46 & 2,35 \\
\hline
\end{tabular}

Hal ini terjadi diakibatkan oleh kadar lignin Eugenia sp yang lebih rendah daripada Lithocarpus korthalsii sp yaitu 25,25 \%, sedangkan Lithocarpus korthalsii lebih tinggi yaitu $28,74 \%$. Dengan demikian dapat dikemukakan bahwa kadar lignin sangat mempengaruhi kecepatan dekomposisi suatu bahan. Hal ini didukung oleh Hakim et al (1986) yang menyatakan bahwa lignin merupakan senyawa yang paling resisten sehingga sukar untuk didekomposisi.

Luas daun tidak berpengaruh terhadap kecepatan dekomposisi. Eugenia $s p$ memiliki luas daun 29,5 $\mathrm{cm}^{2}$ dan Lithocarpus korthalsii 91,6 $\mathrm{cm}^{2}$, sebagaimana disebutkan Users (1999) bahwa daun yang memiliki luas yang lebih tinggi lebih mudah terdekomposisi. Eugenia 
$s p$ yang mempunyai luas daun yang sempit mempunyai kandungan lignin yang rendah sehingga lebih cepat terdekomposisi. Lain halnya dengan Lithocarpus korthalsii yang mempunyai kandungan lignin yang tinggi. Pada setiap posisi topografi nilai $\mathrm{k}$ yang paling tinggi untuk kedua jenis spesies tumbuhan didapatkan pada posisi kaki bukit, tengah lereng, dan yang paling rendah pada posisi puncak buklit. Tingginya nilai k pada posisi kaki bukit erat kaitannya dengan kelembaban tanah.

\section{Perubahan Nisbah C/N Selama Proses Dekomposisi}

Nisbah C/N merupakan salah satu peubah untuk mengetahui tingkat dekomposisi. Kecepatan dekomposisi dapat diamati dari penurunan nisbah $\mathrm{C} / \mathrm{N}$. Nisbah $\mathrm{C} / \mathrm{N}$ selama proses dekomposisi dapat dilihat pada Gambar 2.

Dari Gambar 2 dapat dilihat bahwa nisbah $\mathrm{C} / \mathrm{N}$ cenderung menurun dari bulan ke bulan. Penurunan nisbah $\mathrm{C} / \mathrm{N}$ spesies tumbuhan Eugenia sp lebih cepat daripada Lithocarpus korthalsii. Penurunan nisbah $\mathrm{C} / \mathrm{N}$ Eugenia sp lebih cepat daripada Lithocarpus korthalsii. Spesies tumbuhan Eugenia sp mempunyai nisbah $\mathrm{C} / \mathrm{N}$ yang
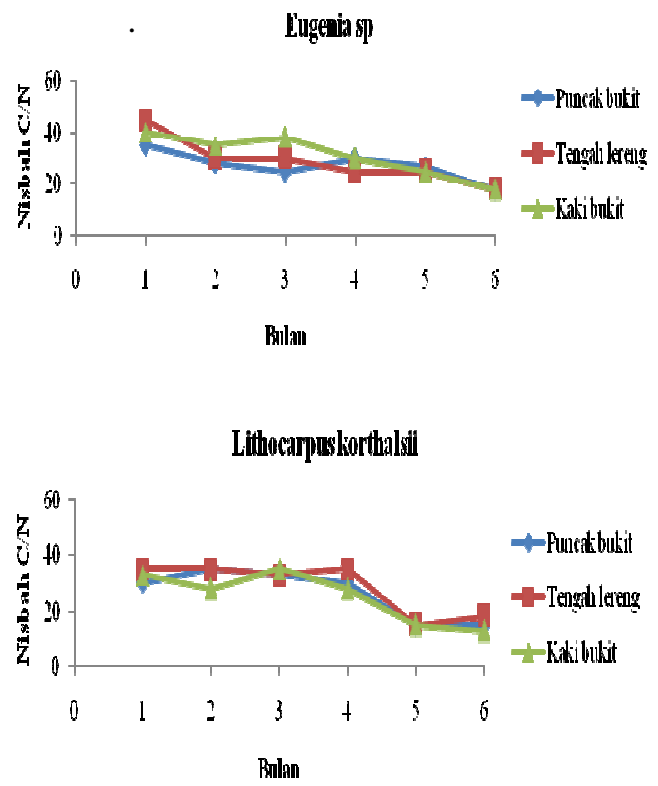

Gambar 2. Fluktuasi perubahan nisbah $\mathrm{C} / \mathrm{N}$ 2 jenis tumbuhan pada 3 posisi topografi selama 6 bulan proses dekomposisi. tinggi. Sampai dengan bulan ke-6 pada puncak bukit nisbah C/N-nya 16,30 pada tengah lereng 15,81 dan pada kaki bukit 14,59 (Tabel 4). Sedangkan penurunan nisbah $\mathrm{C} / \mathrm{N}$ pada Lithocarpus korthalsii tidak begitu nyata pada bulan pertama sampai dengan bulan ke-4, akan tetapi pada bulan ke-5 dan ke-6 penurunan nisbah $\mathrm{C} / \mathrm{N}$ nya nyata. Pada bulan ke-6 sampai 15,35 pada puncak bukit, 16,69 pada tengah lereng dan 13,99 pada kaki bukit (Tabel 4).

Penurunan nisbah $\mathrm{C} / \mathrm{N}$ selama proses dekomposisi dapat diakibatkan oleh penurunan persentase $\mathrm{C}$ yang lebih tinggi daripada persentase N. Mikroorganisme menggunakan unsur $\mathrm{C}$ untuk menyusun selnya dengan membebaskan $\mathrm{CO}_{2}$ serta dihasilkan senyawa-senyawa lain sebagai hasil dekomposisi. Kebutuhan C diambil mikroorganisme dari bahan organik sehingga selama proses dekomposisi terjadi penurunan persentase C. Rao (1994) menyatakan bahwa nisbah $\mathrm{C} / \mathrm{N}$ sangat ditentukan oleh banyaknya bahan organik yang dapat dengan cepat dimanfaatkan oleh mikroorganisme dekomposer (perombak) yang dikandung oleh suatu bahan organik.

Tabel 4. Nisbah nisbah C/N setelah 6 bulan proses dekomposisi pada tiga posisi topografi.

\begin{tabular}{lccc}
\hline Posisi & \multicolumn{2}{c}{ Jenis Spesies } & Rata- \\
\cline { 2 - 3 } Topografi & $\begin{array}{c}\text { Eugenia } \\
\text { sp }\end{array}$ & $\begin{array}{c}L . \\
\text { korthalsii }\end{array}$ & rata \\
\hline $\begin{array}{l}\text { Puncak } \\
\text { bukit }\end{array}$ & 16,21 & 15,52 & 15,86 \\
$\begin{array}{l}\text { Tengah } \\
\text { lereng }\end{array}$ & 15,50 & 17,13 & 16,31 \\
$\begin{array}{l}\text { Kaki } \\
\text { bukit }\end{array}$ & 14,72 & 14,10 & 14,41 \\
Rata-rata & 15,48 & 15,58 & \\
\hline
\end{tabular}

\section{Fluktuasi Kadar Unsur Hara Bahan Serasah Daun Selama Proses Dekomposisi}

Semakin banyak kandungan bahan organik yang dapat dimanfaatkan maka penurunan nisbah $\mathrm{C} / \mathrm{N}$ juga semakin cepat. Kecepatan penurunan kandungan $\mathrm{C}$ ini 
dipengaruhi oleh kandungan oksigen $\left(\mathrm{O}_{2}\right)$ atau aerase dan jenis bahan organik yang akan dirombak

\section{Fluktuasi Nitrogen (N).}

Sumber utama $\mathrm{N}$ dalam tanah adalah dari dekomposisi bahan organik, terutama pada jaringan tumbuhan (Hakim et al, 1986). Fluktuasi persentase $\mathrm{N}$ yang terisa selama 6 bulan proses dekomposisi dapat dilihat pada Gambar 3. Persentase N yang tersisa selama proses dekomposisi menurun setiap waktunya. Maksudnya disini adalah pada setiap bulannya terjadi pembebasan $\mathrm{N}$ ke tanah oleh mikroorganisme. Namun ada juga terjadi peningkatan persentase $\mathrm{N}$, hal ini terjadi karena penumpukkan unsur $\mathrm{N}$ oleh mikroorganisme selama terjadinya proses dekomposisi (Users, 1999) dan penambahan $\mathrm{N}$ melalui air hujan.

Pada spesies tumbuhan Eugenia $s p$ penurunan persentase $\mathrm{N}$ yang tersisa terjadi secara cepat sampai dengan bulan ke-3, hal ini terjadi karena adanya curah hujan yang tinggi pada lokasi penelitian ini. Curah hujan
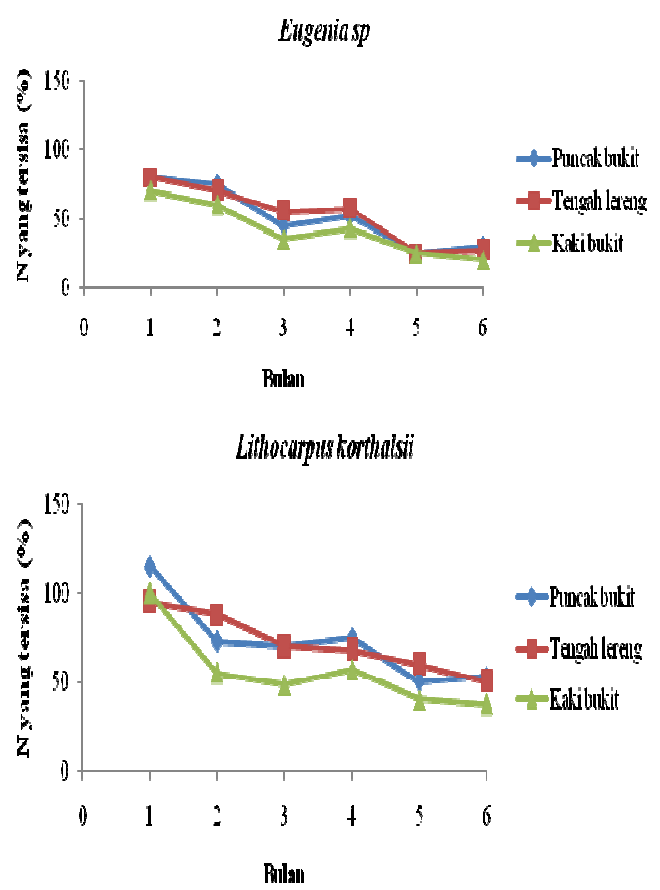

Gambar 3. Fluktuasi perubahan $\mathrm{N}$ yang tersisa 2 jenis spesies tumbuhan pada 3 posisi topografi selama 6 bulan proses dekomposisi yang tinggi menyebabkan banyaknya $\mathrm{N}$ yang tercuci pada sampel. Akan tetapi pada bulan ke-4 terjadi sedikit peningkatan persentase $\mathrm{N}$ yang tersisa. Hal ini diduga terjadi karena adanya penambahan $\mathrm{N}$ dari perombakan oleh mikroorganime dan juga dari penambahan melalui air hujan pada sampel yang lebih tinggi dari pada $\mathrm{N}$ yang dibebaskan pada proses dekomposisi ke tanah. Selanjutnya terjadi penurunan kembali secara teratur sampai dengan bulan ke-6.

Persentase N yang tersisa pada Lithocarpus korthalsii di bulan pertama tidak memperlihatkan perubahan, bahkan pada puncak terjadi sedikit peningkatan $\mathrm{N}$ yang tersisa dari kondisi awal. Sedangkan pada bulan-bulan berikutnya terjadi persamaan fluktuasi persentase $\mathrm{N}$ yang tersisa dengan Eugenia sp. Walaupun mempunyai kecenderungan yang sama namun penurunan persentase $\mathrm{N}$ pada Eugenia sp lebih cepat daripada Lithocarpus korthalsii. Ini berhubungan dengan kecepatan dekomposisi dimana apabila proses dekomposisi cepat maka pelepasan $\mathrm{N}$ juga akan cepat.

Untuk melihat pengaruh jenis spesies tumbuhan dan posisi topografi terhadap persentase $\mathrm{N}$ yang tersisa telah dilakukan analisis statistik. Tabel 5 memperlihatkan pengaruh jenis spesies tumbuhan dan posisi topografi terhadap persentase $\mathrm{N}$ yang tersisa selama 6 bulan proses dekomposisi.

Tabel 5. N-total yang tersisa setelah proses dekomposisi .

\begin{tabular}{lccc}
\hline \multirow{2}{*}{ Posisi } & \multicolumn{2}{c}{ Jenis Spesies } & Rata- \\
\cline { 2 - 3 } Topografi & $\begin{array}{c}\text { Eugenia } \\
\text { sp (\%) }\end{array}$ & $\begin{array}{c}\text { Lorthalsii } \\
\text { rata }\end{array}$ & $\begin{array}{c}\text { rat } \\
(\%)\end{array}$ \\
\hline $\begin{array}{l}\text { Puncak } \\
\text { bukit }\end{array}$ & 34,46 & 54,45 & 44,45 \\
$\begin{array}{l}\text { Tengah } \\
\text { lereng }\end{array}$ & 31,30 & 48,30 & 39,80 \\
Kaki & & & \\
bukit & 29,94 & 40,71 & 32,83 \\
\hline Rata-rata & $30,23 \mathrm{~b}$ & $47,82 \mathrm{a}$ & \\
\hline
\end{tabular}


Angka-angka yang diikuti oleh huruf kecil yang sama pada baris yang sama berbeda tidak nyata menurut uji BNT pada taraf $5 \%$.

Dari Tabel 5 dapat dilihat bahwa jenis spesies memberikan pengaruh yang nyata terhadap $\mathrm{N}$ yang tersisa selama proses dekomposisi. Namun posisi topografi dan interaksi keduanya tidak memberikan pengaruh yang nyata terhadap $\mathrm{N}$ yang tersisa. Bila dilihat dari pengaruh jenis spesies, spesies Eugenia sp lebih cepat membebaskan $\mathrm{N}$ ke tanah, karena $\mathrm{N}$ yang tersisa sedikit yaitu 30,23 \%. Sedangkan Lithocarpus korthalsii $\mathrm{N}$ yang tersisa secara angka-angka berbeda antara puncak bukit, tengah lereng, dan kaki bukit. Unsur N yang hilang selama proses dekomposisi paling tinggi pada posisi kaki bukit, dimana $\mathrm{N}$ yang tersisa hanya 32,83\%, pada tengah lereng $39,80 \%$ dan yang paling rendah pada puncak bukit, dimana $\mathrm{N}$ yang tersisa yaitu 44,45\%.

Hal ini terjadi karena selama proses dekomposisi protein diuraikan menjadi ammonium, dimana ammonium ini nantinya akan diubah menjadi nitrat melalui proses nitrifikasi. Proses nitrifikasi ini merupakan oksidasi enzimatik yang dipengaruhi oleh kelembaban, suhu, aerase, adanya $\mathrm{Ca}$ dan tersedianya ammonium (Hakim et al, 1986).

Berdasarkan data diatas maka setelah 6 bulan dekomposisi Eugenia sp yang mempunyai berat kering 1 ton dapat menyumbangkan $6,78 \mathrm{~kg} \mathrm{~N}$, sedangkan Lithocarpus korthalsii menyumbangkan 9,37 N pada ekosistem hutan.

\section{Fluktuasi Posfor (P).}

Sumber $\mathrm{P}$ dalam tanah salah satunya adalah pengembalian unsur $\mathrm{P}$ melalui sisasisa tumbuhan dan bahan organik lain. Dalam tubuh tumbuhan $\mathrm{P}$ terdapat dalam bentuk P-organik, kemudian P-organik tersebut dimineralisasi menjadi P-anorganik yang tersedia bagi tumbuhan.

Dari Gambar 4 dapat dilihat bahwa penurunan persentase $\mathrm{P}$ tajam pada bulan pertama sampai bulan ke-3 pada Eugenia sp, sedangkan pada bulan ke-3 sampai dengan bulan ke-6 penurunan persentase $\mathrm{P}$ terjadi secara perlahan-lahan. Pada Lithocarpus korthalsii penurunan persentase $\mathrm{P}$ yang tersisa tajam pada bulan ke-2, sedangkan pada bulan berikutnya sampai dengan bulan ke-6 penurunannya tidak begitu nyata, bahkan ada yang meningkat lagi. Hal ini diduga terjadi karena adanya penunpukkan $\mathrm{P}$ oleh mikroorganisme berupa polimer nukleo protein, nucleid acid, inositol fosfat dan ester lain. Peningkatan persentase ini juga didapatkan pada spesies Eurya accuminata dan Quercus argentata, dimana persentase P yang tersisa sampai 150 \% (Users, 1999).
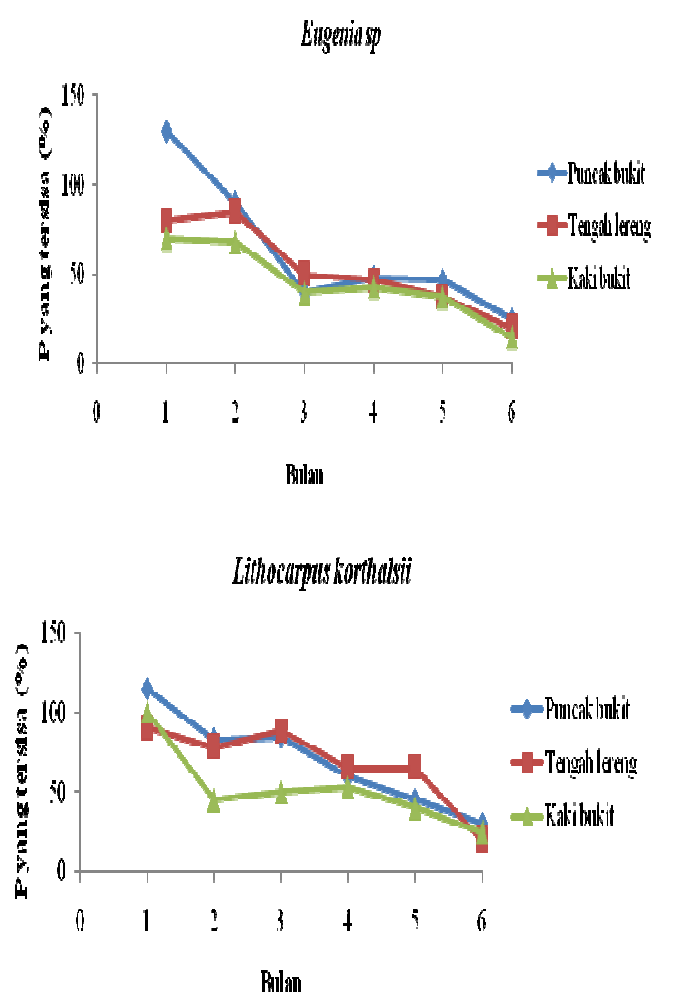

Gambar 4.Fluktuasi perubahan $\mathrm{P}$ yang tersisa 2 jenis spesies tumbuhan pada 3 posisi topografi selama 6 bulan proses dekomposisi

Untuk melihat perbedaan persentase $\mathrm{P}$ yang tersisa pada ke-2 spesies tumbuhan pada posisi topografi dilakukan analisis statistik. Pengaruh interaksi jenis spesies tumbuhan dan posisi topografi terhadap $\mathrm{P}$ yang tersisa setelah 6 bulan dekomposisi ditampilkan pada Tabel 6.

Dari Tabel 6 dapat dilihat bahwa jenis spesies tidak memberikan pengaruh yang nyata terhadap $\mathrm{P}$ yang tersisa. Begitu juga dengan posisi topografi dengan interaksi keduanya juga tidak memberikan pengaruh yang nyata terhadap $\mathrm{P}$ yang tersisa selama 
proses dekomposisi. Dari Tabel 8 terlihat juga bahwa pada spesies Eugenia sp $\mathrm{P}$ yang tersisa lebih rendah (20,13\%) daripada

Tabel 6. $\mathrm{P}$ tersisa setelah 6 bulan dekomposisi

\begin{tabular}{lccc}
\hline \multirow{2}{*}{$\begin{array}{l}\text { Posisi } \\
\text { topografi }\end{array}$} & $\begin{array}{c}\text { Jenis spesies } \\
\text { iugenia sp }\end{array}$ & $\begin{array}{c}\text { L.korthalsii } \\
\text { (\%) }\end{array}$ & $\begin{array}{c}\text { Rata } \\
\text {-rata } \\
\text { (\%) }\end{array}$ \\
\hline $\begin{array}{l}\text { Puncak } \\
\text { bukit }\end{array}$ & 24,61 & 29,20 & 26,91 \\
$\begin{array}{l}\text { Tengah } \\
\text { lereng }\end{array}$ & 22,06 & 18,55 & 20,31 \\
Kaki bukit & 13,72 & 28,77 & 21,24 \\
\hline Rata-rata & 20,13 & 25,51 & \\
\hline
\end{tabular}

Lithocarpus korthalsii lebih tinggi (25,51 \%). Hal ini terjadi karena Eugenia sp lebih cepat terdekomposisi. Untuk setiap posisi topografi $\mathrm{P}$ yang tersisa secara angka-angka berbeda antara puncak bukit, tengah lereng, dan kaki bukit, dimana $\mathrm{P}$ yang tersisa yaitu antara 20,31 sampai 26,91\%.

Unsur P merupakan komponen utama asam nukleat, dimana selama proses dekomposisi bahan organik menyumbangkan unsur $\mathrm{P}$ sehingga terjadi penurunan $P$ pada sampel. Sebagian P pada tanah adalah posfor organik, dimana oleh jasad renik P-organik dimineralisasi menjadi P-anorganik baru dapat digunakan tanaman. Sumber dari P-organik adalah fitin dan asam nukleat (Tate, 1987).

Berdasarkan data diatas maka setelah 6 bulan didekomposisi Eugenia sp yang mempunyai berat kering 1 ton dapat menyumbangkan $0,43 \mathrm{~kg}$ P. Sedangkan Lithocarpus korthalsii menyumbangkan $1,01 \mathrm{~kg}$ P pada ekosistem hutan.

\section{Fluktuasi K}

Sama halnya dengan $\mathrm{N}$ dan $\mathrm{P}$, salah satu sumber $\mathrm{K}$ dalam tanah adalah pengembalian $\mathrm{K}$ melalui sisa-sisa tumbuhan dan jasad renik. Unsur $\mathrm{K}$ yang berasal dari sisa-sisa tumbuhan dan jasad renik merupakan $\mathrm{K}$ yang tersedia bagi tumbuhan (Sutejo, 2002). Persentase $\mathrm{K}$ yang tersisa selama proses dekomposisi dapat dilihat pada Gambar 5.
Pada Gambar 5 terlihat bahwa setiap bulan $\mathrm{K}$ yang tersisa cenderung menurun. Penurunan $\mathrm{K}$ untuk kedua spesies tumbuhan mempunyai kecenderungan yang sama untuk ke-3 posisi topografi. Pada bulan 1 sampai bulan ke-3 persentase $\mathrm{K}$ yang tersisa cenderung menurun, namun pada bulan ke-4 dan ke-5 terdapat sedikit peningkatan persentase $\mathrm{K}$ yang tersisa untuk kedua jenis spesies tumbuhan pada ke-3 posisi topografi.
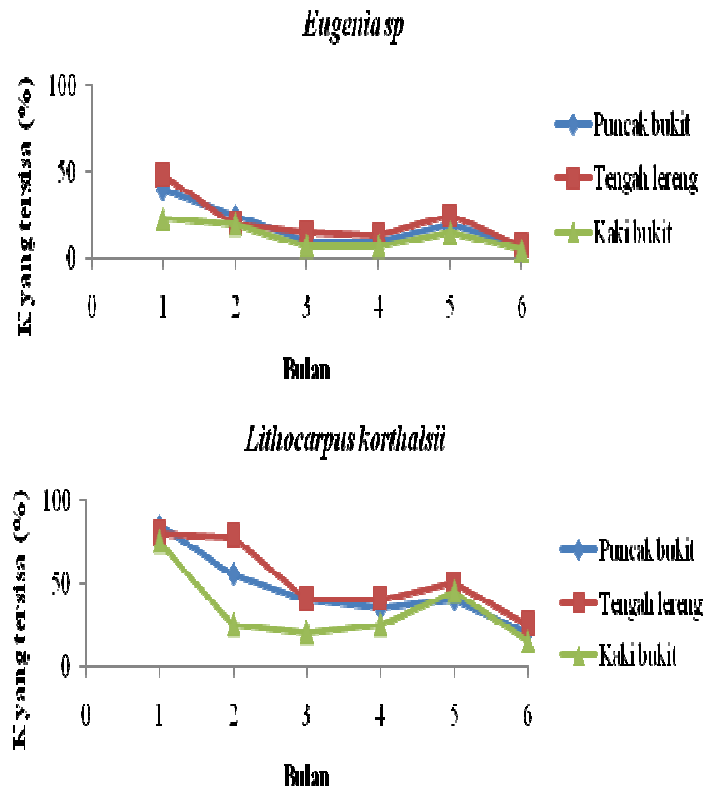

Gambar 5. Fluktuasi perubahan $\mathrm{K}$ yang tersisa 2 jenis spesies tumbuhan pada 3 posisi topografi selama 6 bulan proses dekomposisi

Hal ini disebabkan karena adanya penambahan unsur $\mathrm{K}$ dari kanopi tanaman yang tercuci ke bawah melalui air hujan (Smith, 1982). Curah hujan yang lebih rendah pada bulan ke-4 dan ke-5 menyebabkan unsur $\mathrm{K}$ itu tertahan pada sampel atau tidak tercuci ke bawah. Kemudian pada bulan ke-6 persentase $\mathrm{K}$ yang tersisa menurun lagi dengan curah hujan yang tinggi (Lampiran 5), menyebabkan unsur $\mathrm{K}$ banyak tercuci (Hardjowigeno, 2003). Tisdale dan Nelson (1985) menambahkan bahwa pada daerah tropik yang mempunyai curah hujan dan temperatur yang tinggi mempercepat 
pembebasan dan pencucian K. Walaupun mempunyai kecenderungan yang sama namun penurunan persentase $\mathrm{K}$ yang tersisa pada Eugenia sp lebih cepat.

Tabel 7. K yang tersisa setelah 6 bulan proses dekomposisi.

\begin{tabular}{lccc}
\hline \multirow{2}{*}{$\begin{array}{l}\text { Posisi } \\
\text { topografi }\end{array}$} & $\begin{array}{c}\text { Eugenia } \\
\text { sp }(\%)\end{array}$ & $\begin{array}{c}\text { L.korthalsii } \\
\text { Ran }\end{array}$ & $\begin{array}{c}\text { Rata } \\
\text {-rata } \\
(\%)\end{array}$ \\
\hline $\begin{array}{l}\text { Puncak } \\
\text { bukit }\end{array}$ & 11,18 & 52,89 & 32,0 \\
Tengah & 11,38 & 53,45 & 32,4 \\
lereng & & & 2 \\
Kaki & 7,58 & 39,19 & 23,3 \\
bukit & & & 8 \\
\hline Total & $10,05 \mathrm{~b}$ & $48,51 \mathrm{a}$ &
\end{tabular}

Angka-angka yang diikuti oleh huruf kecil yang sama menurut baris yang sama berbeda tidak nyata menurut uji BNT pada taraf $5 \%$

Berdasarkan data diatas maka setelah 6 bulan dekomposisi Eugenia $s p$ yang mempunyai berat kering 1 ton dapat menyumbangkan 4,12 $\mathrm{kg} \mathrm{K}$, sedangkan Lithocarpus korthalsii menyumbangkan 4,61 kg K pada ekosistem hutan.

\section{Fluktuasi Ca}

Dekomposisi sisa-sisa tumbuhan merupakan sumber Ca dalam tanah (Sutejo, 2002). Fluktuasi kandungan Ca yang tersisa selama 6 bulan proses dekomposisi dapat dilihat pada Gambar 6. Dari Gambar 6 terlihat bahwa spesies Eugenia $s p$ melepaskan Ca secara cepat pada bulan pertama. Untuk bulan selanjutnya sampai dengan bulan ke-4 terjadi sedikit peningkatan $\mathrm{Ca}$ kembali. Hal ini diduga terjadi adanya penambahan $\mathrm{Ca}$ dari abu semen Padang. Debu semen Padang yang terdapat di Ulu Gadut mencapai 12,42 $\mathrm{mg} / \mathrm{mm}^{2}$, yang mengandung 50,04 \% CaO (Pusat Studi Lingkungan Hidup, 1984). Adanya curah hujan yang lebih rendah pada bulan ke-4 dan ke-5 (Lampiran 5) menyebabkan Ca dari debu semen Padang tidak banyak tercuci dan menumpuk pada sampel. Kemudian terjadi penurunan kembali pada bulan ke-6 karena adanya curah hujan yang tinggi, menyebabkan Ca pada sampel tercuci. Dimana Ca mudah sekali hilang melalui pencucian (Soepardi, 1983).

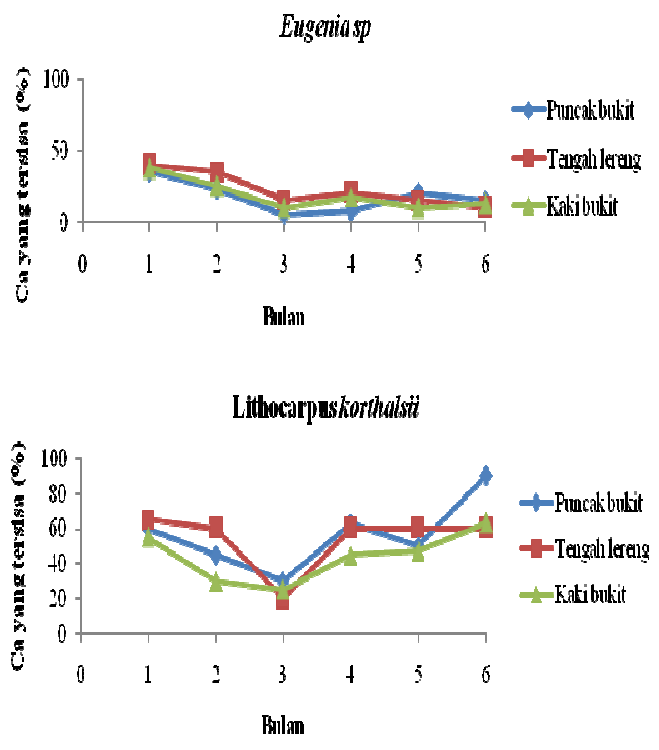

Gambar 6. Fluktuasi perubahan Ca yang tersisa 2 jenis spesies tumbuhan pada 3 posisi topografi selama 6 bulan proses dekomposisi

Pada spesies tumbuhan Lithocarpus korthalsii juga mengalami hal yang sama dengan Eugenia $s p$ dimana terjadi penurunan dan peningkatan Ca yang tersisa selama proses dekomposisi. Pada bulan pertama sampai ke-3 terjadi penurunan persentase Ca secara drastis, namun untuk bulan berikutnya terjadi peningkatan persentase $\mathrm{Ca}$ kembali secara nyata. Rendahnya Ca pada Lithocarpus korthalsii menyebabkan penambahan $\mathrm{Ca}$ dari debu semen Padang terlihat nyata.

Pengaruh jenis spesies dan posisi topografi terhadap persentase $\mathrm{Ca}$ yang tersisa setelah 6 bulan proses dekomposisi terdapat pada Tabel 8. Dari Tabel 8 dapat dilihat bahwa jenis spesies memberikan pengaruh yang nyata terhadap $\mathrm{Ca}$ yang tersisa setelah 6 bulan. Akan tetapi posisi topografi dan interaksi keduanya tidak memberikan pengaruh yang nyata terhadap 
Ca yang tersisa. Namun secara angka-angka dapat dilihat bahwa Ca yang tersisa lebih rendah pada Eugenia sp dibandingkan Lithocarpus korthalsii, dimana $\mathrm{Ca}$ yang tersisa pada Eugenia sp 10,19 \%, sedangkan Lithocarpus korthalsii lebih tinggi yaitu $60,66 \%$. Pada posisi topografi walaupun berbeda tidak nyata, namun dari angkaangka dapat dilihat bahwa Ca yang tersisa pada puncak bukit paling tinggi diikuti tengah lereng dan kaki bukit yaitu 38,88; 35,$13 ; 34,23 \%$.

Tabel 8. Ca yang tersisa setelah 6 bulan proses dekomposisi

\begin{tabular}{|c|c|c|c|}
\hline \multirow{2}{*}{$\begin{array}{l}\text { Posisi } \\
\text { topografi }\end{array}$} & \multicolumn{2}{|c|}{ Jenis spesies } & \multirow{2}{*}{$\begin{array}{l}\text { Rata- } \\
\text { rata } \\
(\%)\end{array}$} \\
\hline & $\begin{array}{c}\text { Eugenia } \\
\text { sp (\%) }\end{array}$ & $\begin{array}{c}\text { L. korthalsii } \\
\text { (\%) }\end{array}$ & \\
\hline $\begin{array}{l}\text { Puncak } \\
\text { bukit }\end{array}$ & 13,17 & 64,59 & 38,88 \\
\hline $\begin{array}{l}\text { Tengah } \\
\text { lereng }\end{array}$ & 9,61 & 56,70 & 35,13 \\
\hline $\begin{array}{l}\text { Kaki } \\
\text { bukit }\end{array}$ & 7,78 & 60,69 & 34,23 \\
\hline Rata-rata & $10,19 \mathrm{~b}$ & 60,66 a & \\
\hline
\end{tabular}

Perbedaan persentase Ca yang sangat nyata setelah 6 bulan proses dekomposisi antara Eugenia sp dan Lithocarpus korthalsii diduga karena perbedaan kadar Ca pada serasah daun. Daun Lithocarpus korthalsii yang berkadar $\mathrm{Ca}$ rendah terlihat nyata menumpuk Ca yang berasal dari debu semen Padang. Dimana penambahan Ca tidak nyata pada bahan yang mempunyai $\mathrm{Ca}$ lebih tinggi.

Pembebasan unsur hara Ca dari tanaman melalui daun yang jatuh tidak berarti dibandingkan N, P, dan K (Tate, 1987). Aflizar (2003) mengemukakan bahwa Ca pada daun lebih tinggi daripada Ca pada tanah. Ca ini pada tanah akan mudah sekali hilang melalui erosi, pencucian dan diangkut tanaman. Pada daerah tropik Ca mudah sekali hilang melalui pencucian akibat curah hujan yang tinggi (Hakim et al, 1986).

Berdasarkan data diatas maka setelah 6 bulan dekomposisi Eugenia sp yang mempunyai berat kering 1 ton dapat menyumbangkan $38,78 \mathrm{~kg} \mathrm{Ca}$, sedangkan
Lithocarpus korthalsii menyumbangkan 3,67 kg Ca pada ekosistem hutan.

\section{KESIMPULAN}

1. Tumbuhan yang berkadar Ca tinggi (Ca accumulator) lebih cepat terdekomposisi daripada tumbuhan yang berkadar $\mathrm{Ca}$ rendah (Ca excluder).

2. Laju dekomposisi paling cepat pada kaki bukit, diikuti oleh tengah lereng, dan puncak bukit untuk ke-2 jenis speceis.

3. Selama proses dekomposisi terjadi pembebasan unsur hara kedalam tanah oleh mikroorganisme. Untuk 1 ton berat kering serasah tumbuhan Eugenia sp. setelah 6 bulan dekomposisi akan menyumbangkan 6,78 kg N, 0,43 kg P, 4,12 kg K, dan 38,76 kg Ca. Sedangkan Lithocarpus korthalsii menymbang kan 9,37 kg N, 1,01 kg P, 4,61 kg K dan 3,67 kg Ca.

\section{DAFTAR PUSTAKA}

Aflizar. Z. 2003. Serasah dan karakteristik fisika dan unusr hara tanah hutan hujan tropik super basah di PinangPinang. Tesis. Program Pascasarajana Universitas Andalas. Padang .141 halaman.

Hakim. N; M.Y.Nyakpa; A.M.Lubis; S.G.Nugroho;M.R.Saul; M.A.Diha; G.B.Hong dan H.H. Bailey. 1986. Dasar-Daar Ilmu Tanah . Universitas Lampung. Lampung, 488 halaman.

Hardjowigeno.S.2003. Ilmu tanah. Akademi Presindo.Jakarta.286 halaman.

Hermansah;

T.Masunaga; D.Kubota;U.William;

T.Wakatsuki.1998.

Nutritional Chracteristics of tree speceis in a tropical rain forest West Sumatra .Nitrogen and Carbon Status. Faculty of life and environmental Science. Shimane University.

Hermansah;T.Masunaga; T.Wakatsuki and Aflizar. 2003. Dynamics of litter 
production and its quality in relation to climate factor in a super wet tropical rain forest West Sumatra, Indonesia. Tropics. 12(2) 115-130.

Hobbie, S.E and P.M. Vitousek. 2000. Nutrient Limitation of Decomposition in Hawaian Forest. Ecological Society of America J. 81 (7).pp. 1867-1877.

Hotta, M.R.Tamin:; M.Ito. 1984. Flora of Gunung Gadut Area. Forest Ecology and Flora of Gunung Gadut West Sumatra. Sumatra Nature Study.pp.10-14.

Masunaga, T.; D.Kubota ; M.. Hotta ; T.Wakatsuki. 1977. Nutritional characteristics of mineral elements in tree speceis of tropical rain forest, West Sumatra. Soil Sci. and Plant Nutr. 44 (3) pp.405-418.

Muldjadi, D. 1999. Penuntun analisa tanaman. Buletin Teknik Pertanian IPB. Bogor.47 halaman.

Pusat Studi Lingkungan Hidup. 1984. Studi analisa dampak lingkungan PT.Semen Padang . Universitas Andalas.Padang. 201 halaman.

Regina, S;T. Tarazona, 2001. Nutrient cycling in a natural beech forest and adjacent plated fine in northern spain. Institute of Chartered Foresters.pp.1128.

Smith, OC. 1982. Soil Microbilogy a model of decomposition and nutrient cycling. Crc. Press Inc.Bocabaron. Florida.273 halaman.

Sundara Pandian, S.M.; P.S. Swamy 1999. Litter production and litter decomposition of selected tree speceis in tropical forest at Kodayarin.The western Ghats India. Forest Ecoligy and Management 123. pp.231-244.
Sutedjo, Mul Mulyani 2002. Pupuk dan cara pemupukan> Rineka Cipta.Jakarta.177 halaman.

Tisdale,S.T. and W.I. Nelson. 1985. Soil Fertility and fertilizer . Third Macmillan Publishing .Co.Inc. New York. 430 pp.

Users, W. 1999. Tree bark nutritional characteristics in tropical rain forest West Sumatra, Indonesia. Mater Thesis Shimane University Japan. Pp 36-49.

Wakatsuki, T: A.Saidi; A. Rasyidin. 1986. Soil in toposequence of Gunung Gadut Tropical rain forest. West Sumatra, Southeast Asian Studies 24(3); pp 243-262.

Winarto. 2003. Makalah pengantar sains (IPPS 702). Program Pascasarajan S3 IPB Bogor. Poster 8 Novemer 8 November 2003.

Yoneda;T, R.Tamin :K.Ogino. 1984. Forest ecologi and Flora of Gunung Gadut, West Sumatra. Sumatra nature Study.pp 38-48. 
